\title{
Life During the Covid-19 Pandemic, From an Economic and Health Point of View
}

\author{
Abdul Rauf ${ }^{\star}$, Dhea Zatira ${ }^{2}$, Metha Dwi Aprianti ${ }^{3}$ Nining Purwaningsih ${ }^{4}$, Lisdewi Mulyati ${ }^{5}$ \\ 1,2,3 University of Muhammadiyah Tangerang \\ abdulrauff1974@gmail.com $\left.{ }^{1 *}\right)$
}

\begin{abstract}
Abstrak
Seminar Kehidupan Di Masa Pandemic Covid-19, Dari Segi Ekonomi dan Kesehatan adalah kegiatan untuk memberikan pengetahuan dan gambaran mengenai virus covid19 dan pemanfaatan ekonomi keluarga dalam meningkatkan kesejahteraan. Adapun tujuan dari pelaksanaan kegiatan yang dilakukan ini adalah Memberikan pemahaman dan pengetahuan mengenai virus covid-19, Sharing dengan dokter dan team kesehatan Rs. Hermina Bitung, Memberikan pelatihan dalam memanfaatkan ekonomi keluarga dan Memberikan pelatihan pengenalan manajemen keuangan bagi keluarga dan perencanaan keuangan keluarga.
\end{abstract}

Kata kunci: Ekonomi, Kesehatan, Covid-19

\begin{abstract}
Seminar on Life in the Covid-19 Pandemic Period, in terms of economy and health is an activity to provide knowledge and descriptions of the covid-19 virus and the use of the family economy in improving welfare. The purpose of carrying out this activity is to provide understanding and knowledge about the covid-19 virus, sharing with doctors and the health team of Rs. Hermina Bitung, Providing training in utilizing the family economy and Providing training on introduction to financial management for families and family financial planning.
\end{abstract}

Keywords: Economy, Health, Covid-19

\section{Introduction}

The COVID-19 pandemic is a global crisis that not only threatens people's health physically, but also mentally. So much bad news is received, making people worry about themselves, their families, closest friends, and even the environment around them.

Another factor that can trigger anxiety in the community during the COVID-19 pandemic is stress due to social isolation or physical distancing in Large-Scale Social Restrictions (PSBB). Excessive anxiety during quarantine can increase the risk of anxiety, depression, and symptoms of post-traumatic stress. To prevent the spread of COVID-19, the public can do the following:

1. Wash hands regularly. Use soap and water, or an alcohol-based hand sanitizer.

2. Always maintain a safe distance from people who are coughing or sneezing.

3. Wear a mask if physical restrictions are not possible.

4. Do not touch your eyes, nose or mouth. 
5. When coughing or sneezing, cover your mouth and nose with your arm or a tissue.

6. Do not leave the house if you feel unwell.

7. If you have a fever, cough or difficulty breathing, seek medical attention immediately.

From an economic point of view, the importance of health factors for humans will be closely related to the quality of human resources. The high and low quality of human resources $(\mathrm{HR})$ is determined by health status, education and per capita income level (Ananta and Hatmaji, 1985). In economic activities, these three factors will determine the productivity of human resources as an indicator of the quality of human resources (Wisana, 2001).

The impact of the Covid-19 pandemic on the economy can be seen from several aspects, including:

1. Consumption: Consumer's purchasing power weakens so that it affects prices, needs, wants, life style (internet, market place, healthy lifestyle).

2. Distribution: Infrastructure, obstacles to the distribution of goods (eg. the driver is sick, lock down an area/port, limited transportation system, limited manpower at the port) makes the flow of goods take longer.

3. Production: Source of Raw Materials, Processing Process, Machine Maintenance, QC.

4. Important things:

a. Cash Flow (high interest), distrust People/companies hold a lot of cash.

b. People don't know about covid issues and fears.

c. Fast changing currency rates.

d. The control system is not running normally.

e. Legal.

As an effort to overcome this problem, we as UMT permanent lecturers through LSP UMT can do Community Service and work together with doctors from Hermina Bitung Hospital to initiate a "Seminar on Life in the Covid-19 Pandemic Period, From an Economic and Health Point of View".

Seminar on Life in the Covid-19 Pandemic Period, in terms of economy and health, is a series of events and services aimed at building the mental health of the community during the pandemic, as well as assisting in efforts to prevent the spread of COVID-19 so that people can continue their activities but by complying with good health protocols. and right..

\section{Implementation Method}

The schedule for the implementation of the "Seminar on Life During the Covid-19 Pandemic Period, From an Economic and Health Point of View" can be seen in the table below: 
Table 1. Implementation of Seminar Activities

\begin{tabular}{|c|c|c|}
\hline Date / Time & Time & Agenda Activities \\
\hline \multirow[t]{2}{*}{$\begin{array}{l}\text { Thursday, } \\
\text { Februari } 20 \\
2021\end{array}$} & $09.00-09.30$ & $\begin{array}{l}\text { Opening, Speech from the Head of } \\
\text { KKN, Kalideres Village Head, KKN } \\
\text { Supervisor and introduction. }\end{array}$ \\
\hline & $09.30-12.00$ & $\begin{array}{l}\text { Submission of material by Dr. Steven } \\
\text { sp. Ok. Regarding the Covid-19 } \\
\text { pandemic and its impact on health. }\end{array}$ \\
\hline
\end{tabular}

The presentation of material by Mrs. Metha Dwi Apriani SE, MM regarding the use of the family economy during the Covid-19 Pandemic.

Presentation of material by Ms. Dhea Zatira, SE., MM regarding the introduction of financial management for families.

Presentation of material by Mrs. Nining Purwaningsih SE, MM and Dra Lisdewi Mulyati MM Regarding family financial planning.

Question and answer

$12.00-13.00$

Rest, Prayer and Lunch

Closing of the seminar

\section{Results and Discussion}

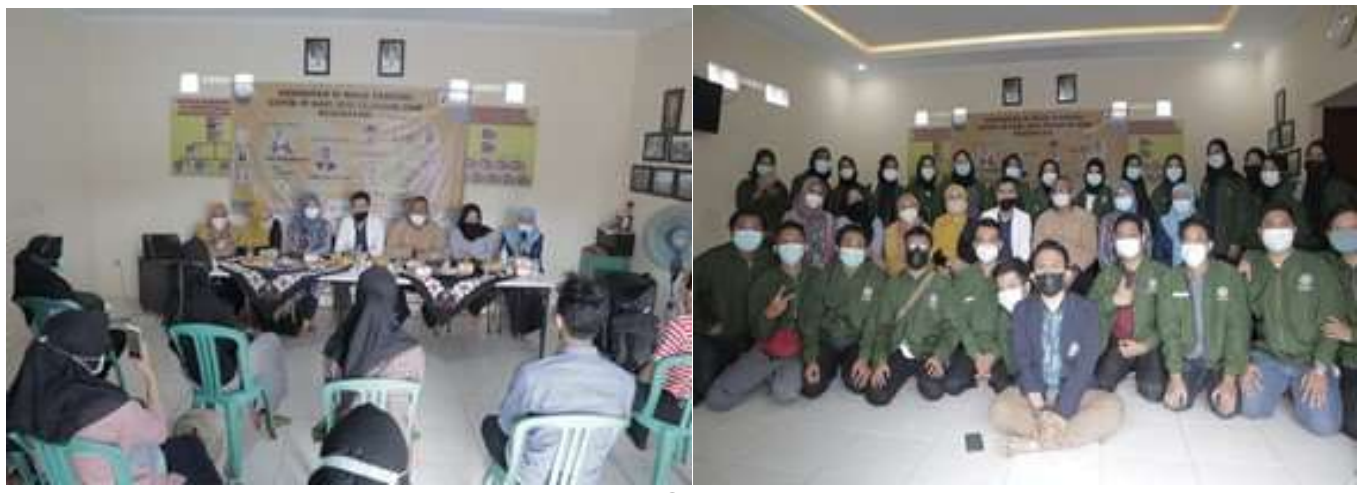

Figure 1. Seminar Activities 
The activity "Seminar on Life During the Covid-19 Pandemic, From an Economic and Health Point of View" which consists of:

1. The Covid-19 pandemic and its impact on family health.

2. Utilization of the creative industry economy in the family

3. Introduction to financial management for families and family financial planning.

4. Check health such as blood pressure and blood sugar.

Problem Solving

1. Covid 19 : people the environment, and the emergency response system.

a. Person :

- Physically healthy (control of diet and comorbid disease),

- psychological/mental,

- social (family,

- spiritual.

b. Community : Health Protocol. Once in a while do a covid screening (if the company has a budget. And focus on the person being screened). Create a special work environment for people with comorbidities.

c. Environment :

- Sunlight and open ventilation.

- Regular cleaning: Vacuum cleaner, Water-Soap, Water-disinfectant, Hot air.

- Emergency Response System:

- Tag people who have comorbid factors.

- Map health facilities around the workplace and make collaborations prepare BPJS/TK cards, ID cards.

- Create a first aid team at work.

- Evacuation exercise.

- Control of sick employees.

2. Economy :

a. Consumption:

- Identify the needs / wants of Target consumers.

- Find out what prices can be bought and still cheap.

- identify the consumer's Life Style --> Create an ad, find the right marketing style.

b. Distribution:

- Look for a more certain and safe way of distributing goods.

- When making a deadline, try to check first with the delivery service.

\section{Conclusion}

From the results of the "Seminar on Life During the Covid-19 Pandemic, in terms of Economics and Health" which was conducted regarding the impact of the COVID-19 pandemic on family health, the use of the family economy, the introduction of financial management and family financial planning had a positive impact on the Kalideres community in particular. PKK women from the Kalideres family in overcoming the current pandemic conditions. 


\section{MOVE: Journal of Community Service and Engagement}

Vol. 01, No. 02, 2021

Page : 47-51

ISSN 2808-2990

References

A. Heri Iswanto. 2021. "Ekonomi Kesehatan: Konsep, Teori dan Aplikasi". Raja Grafindo

Bambang, Riyanto. 2012. Dasar-dasar Pembelanjaan, Edisi 4. Yogyakarta: BPFE.

Brigham Eugene F and Houston,Joel.F.2007. Essentials of Financial Management

I.D.F.K Wisana. 2001. Kesehatan Sebagai Suatu Investasi. Jurnal Ekonomi dan

Pembangunan Indonesia. Vol.1 No.1

https://jepi.fe.ui.ac.id/index.php/JEPI/article/view/613/192

https://www.google.com/search?q=kantorkelurahan+kalideres

https://covid19.go.id/tanya-

jawab?search=Apa\%20yang\%20dimaksud\%20dengan\%20pandemi

Gujarati, Damodar. 1997. Ekonometrika Dasar, Jakarta: Erlangga

Priyoto.,2014. Teori Sikap dan Perilaku dalam Kesehatan. Yogyakarta 